UDC 37.034

DOI: $10.15587 / 2519-4984.2018 .149259$

\title{
UNIVERSAL HUMAN VALUES' NOTION DEVELOPMENT IN MODERN EDUCATIONAL FIELD
}

\author{
(c) O. Andreieva
}

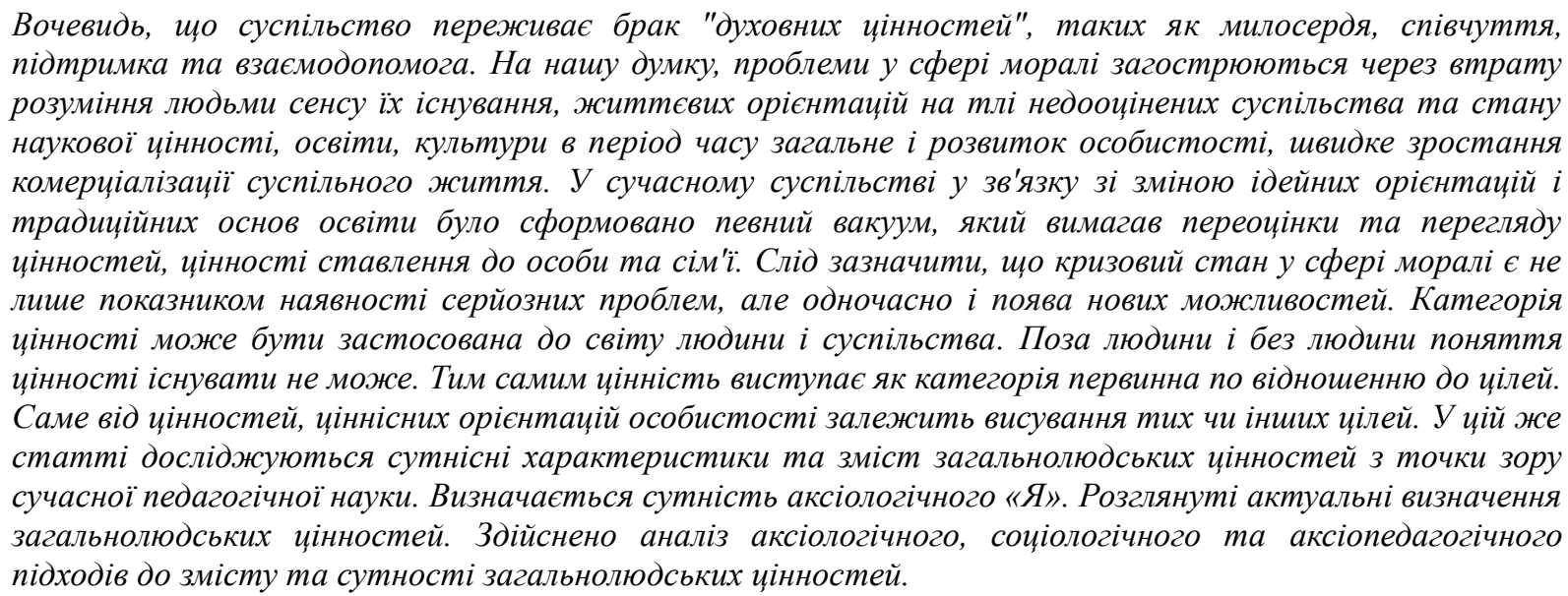
Ця стаття визначає аналіз загальнолюдських иінностей, обтрунтовує думки вчених щзодо підходу та систематизачї изього явища в сучасній науці, визначає теоретичні та методологічні засади педагогічного та психологічного дослідження формування загальнолюдських иінностей, визначає основні напрямки формування аксіологічно структурованої особистості індивида, підкреслює формування загальних иінностей учнів у системі традиційного університету

Ключові слова: загальнолюдські ичінності, моральність, ичіннісна освіта, иіннісний підхід, гуманітарна освіта, аксіологія

\section{Introduction}

Fundamental scientific research in the field of axiological theory proves that humanity faced a real humanitarian catastrophe the prevention of which can only be achieved under conditions of synthesis of the national and universal concepts, combination of the education's importance and the identification of personal and social value orientations teaching students through moral and ethical aspects. It is an essential part of the socialization processes, values of self-determination and selfrealization of the individual. That is why the most relevant question is humanitarian education and justification of the universal human values' phenomenon, and the methodology of their formation which has been explored in the modern scientific space for some time.

In the conditions of the pragmatic transformation of society the study of the universal values' problem, upbringing the universal values of personality in students is not only a philosophical and theoretical but also praxiological, axiological, educational, and social interest. An analysis of the modern theoretical and methodological foundations of the universal values' problem is rising in the field of higher education of Ukraine. Along with this, socio-pedagogical observations encouraged us to highlight various scientifically based perspectives in phenomenology of universal values.

2. Analysis of recent research and publications

Analysis of philosophical and cultural literature, psychological and linguistic scrutiny on the chosen prob- lem's research allowed us to state that scientists made a significant contribution to the substantiation of the categorical apparatus of the values' theory which was supposed to address the axiological questions of their origin and interrelation. The position of pedagogical systemology as a branch of knowledge is grounded, which explores the origin and existence of pedagogical systems, defines their concepts that emerge within the scope of modern pedagogical reality. Based on these theses, we've analyzed the views of the scholars on the justification of the universal human values' development as an axiological category [1]. It is noted that the system-forming factor of the concept of universal human values is the notion of values and value orientations of a society which a person lives and works in. The above argument led to the concept of value, which was generally considered to be all that a person appreciates in his/her life, that one sees a special useful meaning in. Values' education simply means developing appropriate behaviour and habits involving inculcation of certain values and habits. It also refers to a wide gamut of learning activities ranging from mental hygiene, training physical health, civic rights and duties, etiquette and manners, to aesthetic and even religious training. It fosters positive relationships, and it is an explicit goal aimed at promoting care, respect, and cooperation [2]. The main aim of values' education is the ability to make moral judgement based on the sound reasoning. Following Rosana G. Rodriguez and Jose L. Rodriguez [3]: «As a global society continues to expand, we have the choice to co-create a better future for our chil- 
dren by ensuring equity, access and excellence in education as core values that will help transform our world. That choice allows us to become all that we can be as people, through the celebration of our diversity of language, history and culture. It also means that we fully embrace our multilingual society and that we provide full support for all learners which, by definitions, includes excellent bilingual education for English language learners. The inculcation of value based education has become a need of the hour. The need of values and morals can be characterized by various points. Like the follows:

1. For self realization and inner development.

2. To promote fundamental values.

3. To promote individual and social development and well being.

4. To shape our world, outlook and attitude.

5. To sustain the society and culture and bring about necessary changes in the society.

6. To direct people to lead a healthy life.

7. To improve overall qualities of life.

8. To train to become responsible citizens.

9. For moral upliftment of every individual» [3].

\section{The aim and objectives of the study}

The aim of research is to study the way of development of the universal human values' notion in modern educational field.

To achieve the set goal, the following tasks were solved:

1) we have analyzed and defined the notion of universal human values of the personality from the point of philosophical, psychological, pedagogical, social, culturological aspects;

2) regarded the importance of human values' nurturing in modern pedagogical science;

3) studied the importance of value approach implementation, and presented the results of the study in this article.

\section{Presentation of the main research material}

Relying on the logic of the universal human values' analysis and analysis of a personality and a society, we understood and synthesized their origins and development as a common process of emergence, stirring and further development of universal human values in human culture and society that leads to their current state of development and relevance in the education and educational space.

Great thinkers and scientists believed that such values, as goodness, truth, beauty, mind are the source of development and the result of the social needs' influence of society, forming a number of certain values of a man. As the historical and cultural factors of genesis, the notion of value cites the results of the scientific discussions that were held in the philosophy of the 1960's and 70's of the twentieth century. The result of these discussions led to the creation of value's definition which was understood as the essence of morality, ethical ideal, any form of consciousness, relevant to an individual.

The theoretical basis for the definition of value was formed by Maslow [2], and others under the influence of philosophical ideas of axiological theory. It was seen as a positive (useful) significance of objects of the surrounding world for a person, social group, society.
Values are determined based on the discussions of certain scholars, and the concept of a value was defined. We consider the essence of this definition as a fundamental non-social good that optimally ensures the productive functioning of society, social justice, peace, and protection of human beings, respect for human dignity and the creation of socio-cultural conditions for achieving a high standard of living and self-realization of a person. The interpretation of value notion's essence proves the significance of a personality's phenomenon and social practice of a man, his/her conformity to the social needs of individuals, individual social groups, especially the student youth of Ukraine commitment.

The second system-forming factor of the universal values' concept is the notion of values' orientation. Existing series of definitions of value orientations in pedagogical systemology in their essence, structure, hierarchy, and relationality do not contradict each other, but, on the contrary, supplement the meaning of the definition. The epistemological characteristic of the value orientations' concepts form structural and functional attributes that allow them to enter into a single logicalsemantic field of our study, which [4] is a hierarchical structure of many lexical units that are connected. They reflect the concrete conceptual sphere, its structuralfunctional connections, the cognitive-logical interests, reflected in the human mind.

The main definition of the value orientation's concept is given as follows: value orientations are a selective attitude of a man to material and spiritual values, which includes stable patterns, beliefs in advantages that are reflected in the consciousness of the individual and his/her behaviour, the way of individual differentiation of objects belonging to different origins by their significance [4].

Others [5] defines the concept of value orientation as a differentiation and evaluation of objects based on their value for a particular individual; the establishment of the individualized meaning of various objects, the meaningful orientation of the individual, the basis of the interaction with various objects. On these bases, a person has an informed commitment to certain activities that is related to the satisfaction of the personal and social needs of his social practices.

Scientists formulate this determinant as social values that a personality can have and advocate the purpose of life by, moral and ethical guidelines, and is meant for effective achievement of these goals. They become signs of the functions of the most important regulators of social behavior, actions, actions of the individual, on the basis of which people deliberately subordinate their activities to a stable (dominant) personality and social purposes, ready and determined to give all the forces and inspiration in the steady progress for a stated task. Taking into account the creative and objective possibilities of synergetic, systemic and structural approaches, we have formulated, in our opinion, a refined version of the definition of the value orientation of a person. We understand and practically form valuable orientations as a selective and individually conscious, relatively stable system of orientation in the context of motives, interests and personal emotional needs of a person who is purposefully oriented towards a certain sector of social and cultural values and form a meaningful axiological vector 
of human life in the system of social values. Valuable orientations of a person as a subject of social practice represent an individualized set of various guidelines for certain personal and social values in the form of ideals, moral and ethical norms of behaviour, customs, traditions, world outlook and national mentality, which are defined as the value consciousness of a man. Valuable human consciousness, as a product of axiological orientations, reflects its character, methods of incorporating the individual into various forms of social practice, direction of social-human-value raising and self-realization.

The principles of synergetic, structural-system approaches and comparative methods of theoretical research of the axiological notions' origin in our study made it possible to separate qualitative features that have strengthened on cognitive, logical, praxis-logical, behavioural, valuable and motivational basis, health care; harmony of a person, results of social and valuable activities of people and society, etc. Taking into account the theoretical and methodological peculiarities of the definitive analysis, we consider it necessary to give examples of definitions of universal human values in the modern society.

Definite scholars in the field of values' theory [6] prove the concept of universal values as it is regarded as the concept of the values' existence perceived by people in different cultures, life-social status in the form of following axiological content: society, people and their psychological health; dignity, honor, work, decency; family, team, personality.

In philosophy and sociology, the notion of universal human values was considered by numerous scholars who perceived it in the form as a system of axiological categories, the essence of which reflects the notion included in the system of the philosophical doctrine as the highest social value that determines the appearance of other values reflecting common ideals, motives, interests, needs, preferences, beliefs, spiritual and social determinants, moral and ethical norms of the human population.

The scientists consider the concept of the universal values as a definition of cultural science, which characterizes the essence of ideals, principles, moral and ethical norms, rights that have an axiological priority in the life of people, regardless of their social status, nationality, religion, education, age, gender. The axiological essence of the concept of universal human values is also formulated collectively. It is the definition as a system of values, theoretically existing in the plane of morality, ethics, spirituality, culture of a man and society, the content of which is not related to a particular historical stage, period of the development of society or specific ethnic tradition [7]. Asmolov [8] defines the concept of the universal human values as a phenomenon of human culture and society whose axiological nature does not depend on class interests, sympathies, preferences, ideological beliefs. These universal values as a system of axiological categories are equally relevant for representatives of all walks of life, individual social groups. Human values as a form of individual and social axiological consciousness are especially powerfully represented in the world of religion. The constructive position of common-human values is found in educational, social-pedagogical systems, which are aimed to develop a person in accordance with the moral and ethical ideals of society. The formation of values' system in the Ukrainian philosophy of education went through some changes. It's been influenced by the «philosophy of the heart» belonging to Pamfil Yurkevich. On his deep conviction, the center of any life is heart that appears as the deep foundation of human truth, moral and spiritual source of soul activity. It is the bearer of cognitive actions; soul is the center of emotional senses, cares, passions, moral life in general. Even knowledge comes from the activity of the soul: only penetrating into the heart, knowledge can be learned. Yurkevich believed that the heart is capable of expressing, finding and understanding the internal (mental) states of a person who is at a high level of his/her own spirituality and is not available for logical knowledge; abstract knowledge becomes the internal (spiritual) state of a man is not due to reason, but as a result of penetration into the heart, becomes the engine of the spiritual life of a man [9].

We'd like to mention that modern education with predominance of technocratic nature of learning and reproduction of a technocratic type of thinking is extremely inappropriate for our time with its neglect to the spiritual world of personality. Appreciating the values and bringing them to students occurs effective only when they pass through their soul and heart. The educator awakens consciousness of the learners in terms of their responsibility as the valuer, the ones who determine their own value system. This is achieved by inviting the learners to look inward to their inner selves and to examine, how the various systems, which they are a part of, influence their development of values. These systems include family, school, Church, workplace, community, nation, the world and God, i.e. the experience of a higher power.

An urgent need not only for the socio-economic, but also for the spiritual Ukraine directly depends on the state of the education system, its goals and character, the values that it professes. One of the decisive conditions for the success of spiritual development is that people should be regarded as its purpose and the highest value. In general, the Ukrainian philosophy of education is derived from the definition of values necessity, in the correct expression of Ball [10], «At the same time it must be admitted that Ukraine's entry into the 21st century is a fundamentally new stage civilization, it caused insufficiently developed new educational system, since the actual values of education are formed in a controversial time, struggling among traditional, national values and values that give rise to realities of the present, the dramatic changes in the socio-political system and socioeconomic structure». The education of Ukrainian citizens should vitally provoke «a feeling of joy from knowing the world and oneself. A person should remain one of the main educational values»[11].

Also, would like to add, that as trainers, teachers, educators we should not come to the classroom with a set of predetermined values to 'teach' the students. Both educators and students are to be engaged in interaction to explore the meaning of values and beliefs. However, one should admit that, as not only teachers but individuals, we can't stay neutral as we live in culturally structured contextual systems; therefore, we must approach our learners with a general disposition - rooted in some basic values - to be open democratic to dialogue and welcome novelties. Be creative, diverse, and divergent thinker. «Such phenomenon as neutrality does not exist. We al- 
ways take a particular position, which stems from our existential, axiomatic and epistemological beliefs. If we bear on democratic values, we actually should operate according to values and beliefs in tune with principles of justice, respect and ethics in our relations to fellow human beings. In my point of view, when we take a critical and serious standpoint regarding the issue of moral development - unfortunately, often reduced to moral reasoning according to cognitivists and constructivists - we conclude for the need to incorporate social and moral objectives into educational, pedagogical practices.» [12]

\section{Results of the Research}

The results obtained in the course of study, might help in realizing the basic principles of values' education in the educational process and stipulate the guaranteed achievement of the stated goal of educating - the human values of the individual development in the student's youth, based on the theoretical and methodological basis. Thus, the opinions of scientists help to determine the processes of axiologically-structured person formation, to determine the methodological substantiation of sociocultural determinants of education, principles and regularities of the upbringing of universal human values in students at the universities. The theoretical study of the universal human values in modern science, the philosophical, cultural, social, and personal laws of universal human values are set to make it possible to state that phenomenology lies in their constructive genic properties. In connection with the generalization, the question of our further research, which is connected with the necessity to systematize a number of theoretical preconditions of psychological and pedagogical study of the regularities of the common human values' formation, becomes topical. The solution of these issues in the context of the axiological discourse will allow to approach the essence, structure and instrumentality in the formation of universal values in the personality of the students at the present stage of the Ukrainian high education functioning. The traditional model of values education has placed a greater emphasis on the content of values instead of on the valuer. The approach is more teacher-centered, where the educator is seen as both the possessor of knowledge (an expert) and the model of values (an idol). The responsibility therefore, largely rests on the educator. The learner simply adopts a more passive role, merely absorbing the material being handed down. This implies that the educators must themselves be attuned to and up- dated with the different systems, including the intrapersonal system, and their potential effects on the learner. Hopefully, this kind of examination will increase the learners' consciousness, not only with their outer realities, but also with their inner realities. In the process, the learners are to eventually realize their ability to work towards personal integration, wholeness and a sense of harmony within. This means that the values they profess in the cognitive level will be filtered down to the affective as well as the behavioural, thereby making them authentic persons who are true to themselves and a friendly-to-world human. This also involves an effort at finding some form of consistency between what one personally upholds as values with the values that external realities promote, i.e. cultural norms, society's expectations, roles undertaken, and others.

\section{Conclusions}

1) We have analyzed the works of the scholars dedicated to the universal human values object. Summarizing the studied works we can conclude that the common notion of universal human values is reflected in the theory of value orientations which are a selective attitude of a man to material and spiritual values, which includes stable patterns, beliefs in advantages that are reflected in the consciousness of the individual and his/her behaviour, the way of individual differentiation of objects belonging to different origins by their significance.

2) We have regarded the importance of human values' nurturing in modern pedagogical science. Thus, we came to a conclusion that implementing the value approach in education will lead the whole learning experience involved in the valuing process to inevitably heighten the learner's self-awareness, which eventually leads to a spiritual development in self-identity and selfdirection. Consequently, one becomes more fully empowered to take on the role and responsibility of influencing the community around and promote human dignity in all aspects of life. In the humanistic model however, there is a shift. The emphasis is from content- to process based, values-to-valuer-focused and teacher-to-studentcentered orientation. The greater part of the learning this time will involve the valuing process where a dynamic interaction within the individual learner (and educator) and between each other occurs.

3) The importance of value approach implementation has been studied, and the results of the study are presented in the article.

\section{References}

1. Bybler V. S. Nravstvennost. Kultura. Sov-remennost: Fylosofskye razmishlenyia o zhyznennikh problemakh. Moscow: Znanye, 1990. $64 \mathrm{p}$.

2. Maslow A. Samoaktualyzyrovannie liudy: issledovanye psykhycheskoho zdorovia. Saint Petersburg: Evrazyia, 1999. 320 p.

3. Rodriguez R. G., Rodriguez J. L. Many Languages, One Nation: Valuing Bilingual Children. 2008. 201 p.

4. Pedahohycheskyi slovar / Zahviazynskyi V. Y. et. al.; ed. by Zahviazynskyi V. I., Zakirov A. Moscow: Akademyia, (2008). $352 \mathrm{p}$

5. Branco A. U., Valsiner J. Cultural psychology of human values. Charlotte: Information Age Publishers, 2012.312 p.

6. Ovsianetska L. P. Tsinnisni oriientatsii yak faktor zhyttiediialnosti rozvytku osobystosti // Zbirnyk naukovykh prats Prykarpatskoho universytetu imeni Vasylia Stefanyka. Seriia: Filosofiia, sotsiolohiia, psykholohiia. 1998. P. 66-70.

7. Bekh I. D. Vykhovannia osobystosti: textbook. Kyiv: Lybid, 2008. 848 p.

8. Asmolov A. H. O nekotorikh perspektyvnikh yssledovanyiakh smislovikh obrazovanyi lychnosty // Voprosy psykholohyy. 1979. Issue 4. P. 35-46

9. Yurkevych P. D. Fylosofskye proyzvedenyia. Moscow: Pravda, 1990. 670. 
10. Ball H. O. Gumanizatsiya obshhego i professional'nogo obrazovaniya: sotsial'naya deyatel'nost' i psikhologopedagogicheskie orientiry. Nepreryvnoe profesional'noe obrazovanie: problemy iskaniy i perspektiv. Kyiv: Pulsari, 2000.279 p.

11. Yagupov V. V. Pedagogika. Kyiv: Lybid, 2002. 560 p.

12. Matusov E., Lemke J. Values in dialogic pedagogy // Dialogic Pedagogy: An International Online Journal. 2015. Issue 3. doi: https://doi.org/10.5195/dpj.2015.141

Рекомендовано до публікаиії д-р пед. наук, професор Шевченко Г. П. Дата надходження рукопису 25.10.2018

Olena Andreieva, Postgraduate Student, Department of Pedagogy, Volodymyr Dahl East Ukrainian National University, Tsentralnyi ave., 59-a, Severodonetsk, Ukraine, 93400

Email: yeland655@gmail.com

\author{
УДК 378.4: 004 \\ DOI: 10.15587/2519-4984.2018.151557
}

\title{
ОНЛАЙНОВІ ІНСТРУМЕНТИ ВІЗУАЛІЗАЩІЇ У ДІЯЛЬНОСТІ СУЧАСНОГО ПЕДАГОГА
}

\section{(C) Л. І. Білоусова, Н. В. Житеньова}

Хмарні технології відкрили доступ до розмаїття потужних багатофункиіональних програмних інструментів візуалізації різного призначення, використання яких дає змогу вирімувати проблеми інтенсифікації і гуманізація освітнього процесу, його адаптації до потреб, запитів і когнітивних особливостей молодого покоління, підвищення якості й результативності навчання і багатьох інших. Проте впровадження зазначеного інструментарію в широку освітню практику потребує підтримки педагогів в освоєнні простору нових можливостей. Статтю присвячено розробиі класифікаиії онлайнових інструментів візуалізації навчальної інформації, яка б слугувала надійним орієнтиром у виборі ефективного інструмента для вирішення конкретного педагогічного завдання. Виділено шість категорій зазначених інструментів за характером педагогічних завдань, для вирішення яких вони застосовуються: інструменти для створення візуального супроводу викладу навчального матеріалу; інструменти для стиснення, систематизачї та структурування навчального матеріалу; інструменти для створення дидактичних ігор; інструменти для моделювання; інструменти для створення спільного діяльнісного простору для учнів $i$ вчителя; інструменти для реалізації оперативного зворотного зв'язку. У рамках зазначених категорій інструменти згруповано за видами кінцевого продукту - дидактичного засобу, розробленого на засадах використання технологій візуалізації. Загалом йдеться про 34 види таких засобів. Наведено коротку загальну характеристику функиіональних можливостей кожної з груп інструментів $і$ їх перелік для створення відповідного дидактичного засобу. Представлена класифікація охоплює понад 200 сучасних онлайнових інструментів для створення візуальних матеріалів. Інструменти відібрано за їх дієвістю, функціональною спроможністю й ефективністю використання в педагогічній діяльності

Ключові слова: інструменти візуалізачії, педагогічні онлайнові інструменти, класифікація онлайнових інструментів, дидактичні засоби

\section{1. Вступ}

Модернізація освіти не уявляється можливою без оволодіння педагогами новим високотехнологічним інструментарієм, і перш за все - новітніми інструментами підтримки педагогічної і навчальної діяльності, ефективність яких зумовлена використанням технологій візуалізації. Технології візуалізації дають змогу перетворювати великі обсяги навчального матеріалу в формати, компактні і водночас ефективні для його сприйняття, усвідомлення й засвоєння, виступають опорою у вирішенні нагальних педагогічних проблем, таких як інтенсифікація і гуманізація освітнього процесу, його адаптація до потреб, запитів і когнітивних особливостей молодого покоління, підвищення якості й результативності навчання і багатьох інших.

Розмаїття застосувань й затребуваність технологій візуалізації у різних сферах людської діяльності зумовили високі темпи їх розвитку. Попри те, що освітній потенціал цих технологій стрімко нарощується, його освоєння в масовій педагогічній практиці відбувається вкрай повільно. Донедавна об'єк- тивними причинам такого відставання були висока вартість ліцензійних програмних засобів візуалізації, їх складність, вимогливість до технічних характеристик комп'ютерного обладнання, що постало певним бар'єром для широкого застосування таких засобів у закладах освіти. 3 появою хмарних технологій 3'явилась реальна альтернатива традиційному програмному забезпеченню, і це кардинально змінило ситуацію: «протягом 2013-2016 рр. фактично відбулася революційна «глобальна міграція» у хмарні технології» [1]. Хмарні технології не тільки зняли зазначені вище бар'єри, а й відкрили нові можливості використання візуалізації в освітній практиці, забезпечивши вільний доступ до множини потужних багатофункціональних програмних інструментів візуалізації різного призначення i готових візуальних об'єктів, які здатні збагатити арсенал ефективних дидактичних засобів. У таких умовах набуває актуальності підтримка педагогів в освоєнні новітнього онлайнового інструментарію, його введенні у повсякденну освітню практику. Оскільки розвиток тех- 